Maciej Kruszyna

dr hab. inż.

Politechnika Wrocławska,

Wydział Budownictwa Lądowego i Wodnego,

Zakład Dróg i Lotnisk

maciej.kruszyna@pwr.edu.pl

DOI: $10.35117 / \mathrm{A} \_E N G \_17 \_04 \_02$

\title{
Tramways Program as a stimulus for the introduction of less conventional solutions in the field of urban transport infrastructure
}

\begin{abstract}
The multi-annual investment program (here for the extension of tram system in Wroclaw) formulates a large number of tasks. Their effective implementation requires the use of various solutions, including differ from the standard and widely used. In the article the author presents proposed, less conventional solutions in the field of urban transport infrastructure, to be applicable to the tasks of the Wroclaw Tram Program. Two from the nine groups such solutions are discussed in more details: sections of track running along the outer edge of the road and large loops held one-way streets. In conclusion, the article summarized the advantages of the implementation of the proposed solutions. Such realizations are possible to consider in other Polish cities.
\end{abstract}

Keywords: Investments in urban transport infrastructure; Unconventional solutions; Wroclaw Tram Program

\section{Introduction}

Long-term investment programs (including transport infrastructure) require a careful preparation of the timetable, the sequence of tasks and the application of efficient and cost-effective solutions. This seems to be a field for atypical and unconventional solutions, which will increase the set of available technical means, increase the efficiency of the investment (cost-benefit ratio) and thus improve the program's performance..

Within the framework of urban transport infrastructure, for example in [2] (and implemented) solutions are less typical, different from the "standard" way of conducting tram routes in the streets separating the upper classes, implemented together with the road investment. The fact of building (expensive) roads together with the tram route caused the slow pace of development of tram tracks and indirectly raised the costs of implementing the tram program (in the context of the city budget expenditure). Not to mention the dubious accessibility and efficiency of linking the tram route with the surrounding.

In article [11] the recommended ways of shaping tram routes are given. Modern planning of tram routes requires their proximity to the sources and destinations of the passengers. It is advisable (...) as far as possible: routing in the middle of an existing building (...), routing on a line close to the straight (the worse the availability of platforms, the lower the difference between the route and connecting the lines with a straight line), limiting the use of two-critical for the tram speed (...), taking into account the routing of the speed profile, including the location of turnouts or arcs with small radii at the stops (...).

Inspiration and example for less conventional solutions may be the running of a suburban tramway in Linkeheim (Karlsruhe agglomeration) - Figure 1. A narrow lane was introduced in the narrow local street for vehicles with bicycle traffic. The introduction of less typical solutions (often also modeled on foreign projects) has been considered recently in Poland for: Gdańsk [1], Toruń [3], Warsaw [7] or Wroclaw [4][8]. The authors of these proposals emphasize the importance of the means of motion engineering on the effectiveness of the solution [1][3][10] and the conditions for composing the tram route with the surroundings [2][7][8][9][11]. 


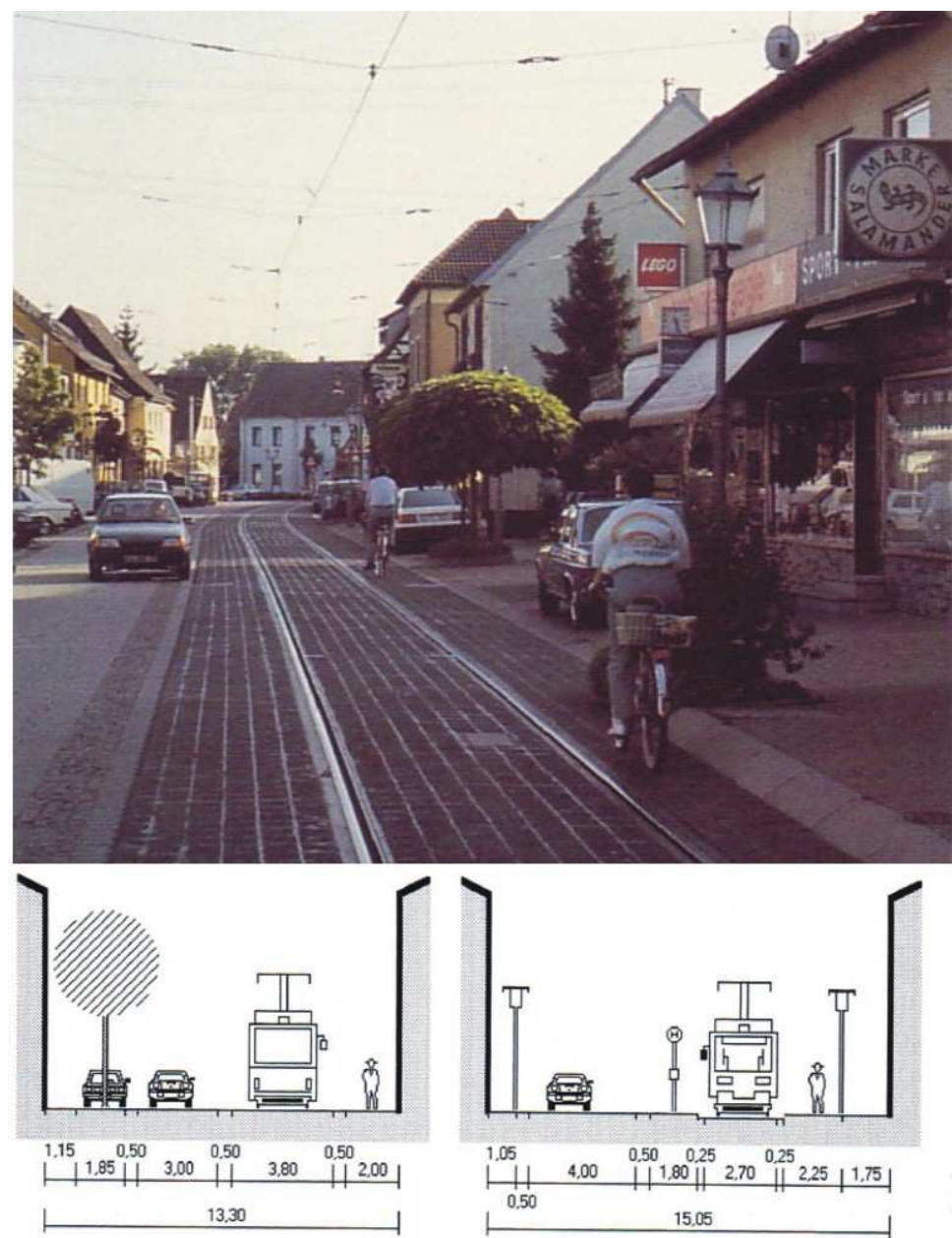

1. Example of entering a rail transport route into a restricted street area, Karlsruher Strasse, Linkenheim, illustration based on [12].

\section{Characteristics of the Wroclaw Tram Program}

The Wrocław Tram Program (WPT) [14] was formulated as a multiannual set of diverse actions aimed at expanding the system, extending the reach of public transport to a larger population and, consequently, improving the allocation of transport tasks. In September 2016 the President of Wroclaw announced the main WPT theses according to the following list.

The WPT objectives are:

- Improved accessibility to the rail transport network,

- Tram network will be expanded more intensively, integrated with rail and buses, city bike, Park and Ride system,

- priority for high traffic standards.

Five key WPT elements have been listed for this purpose:

- extension of the tram network,

- new rolling stock and facilities objects (including depot),

- travelling by tram promotion,

- introduction of a fixed line layout,

- integration with an agglomeration rail.

The basic effects of WPT are:

- short "door to door" travel time (taking into account arrivals, waiting, driving),

- modification of "communication behaviors" (mobility),

- greater share of public transport travel. 
The WPT defines about $60 \div 70 \mathrm{~km}$ of new routes (about 40 investment tasks) to be completed at a rate of $3 \div 4 \mathrm{~km}$ per year. So the whole program is about to be completed in the horizon of about 20 (30) years. For the nearest time perspective (EU funding) it is planned to intensify the "tram" investments, to implement in the horizon of 5 years (up to 2022) about $15 \mathrm{~km}$ of new routes. The basic assumptions for the expansion of the network are: getting to the settlements without tram service (first to large traffic generators, then to other housing estates, to agglomerations, Park and Ride parkings), new tramcorridors in the city center, rebuilding the nodes for increased reliability and traffic efficiency. Figure 2 shows the target network with distinction of planned sections (green line means execution in the horizon until 2022, and cream background in subsequent years).

Directions of development of the network have been recorded in the Transport Plan [13] (see "directions of development") and are to be integrated into urban planning (updated to the end of 2017). The WPT designates the locations of the metro network (tram) with agglomeration (rail), suggesting the location of stops (change of existing, new locations). Agglomeration Railway will serve mainly commuter journeys, although in some connections can complement the public transport network; Interchange stops will be included in the Study, with more stops planned than before, it is possible to implement them within the current perspective of EU funding (for example within the framework of the National Railway Program). It is important to integrate WTP agglomeration plans. It is planned to modify the plans of reactivation of railway connections to Jelcz and Sobotka.

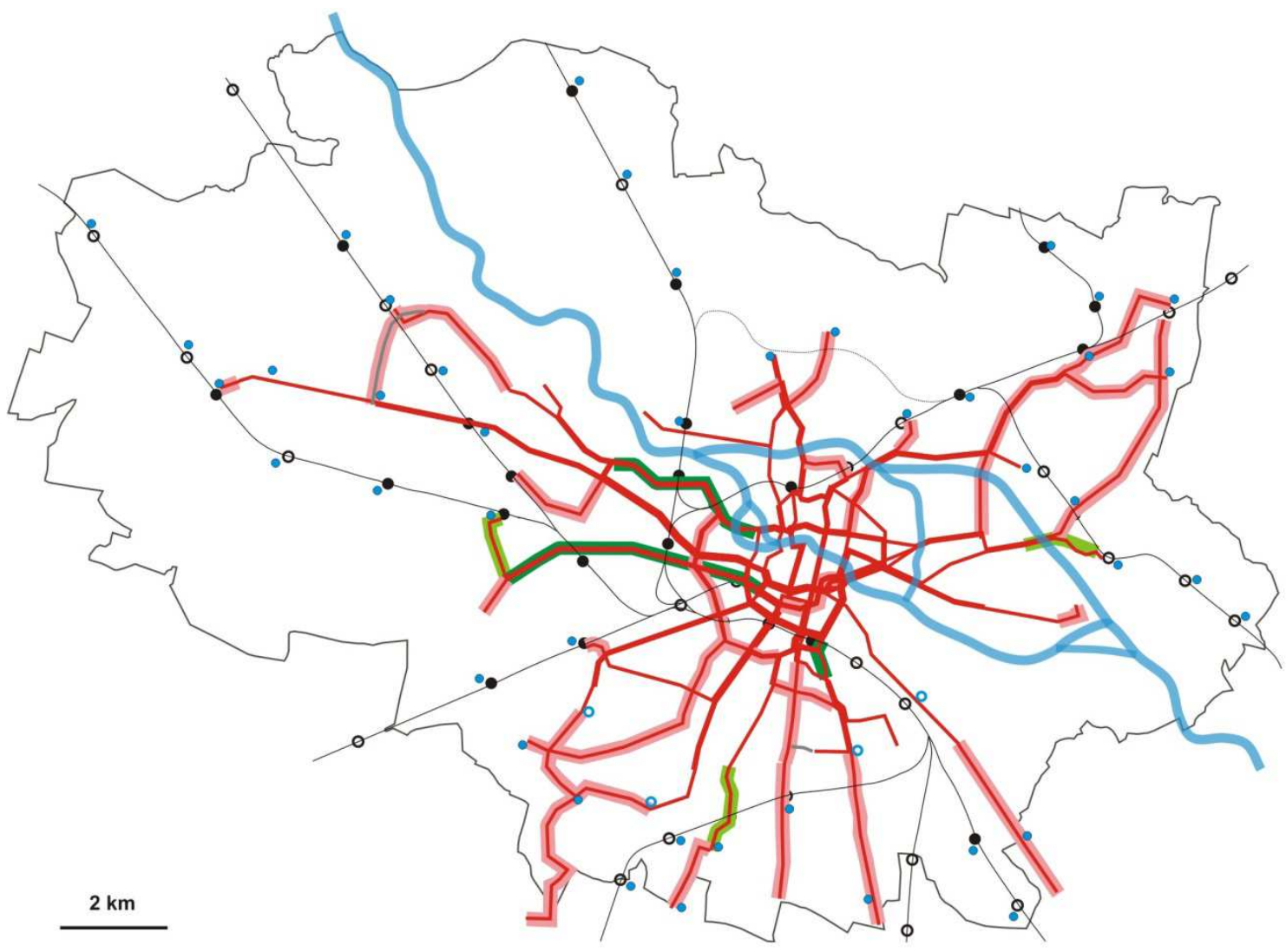

2. Targeted tram network (horizon 2042) according to WPT, map based [5]

\section{Less conventional tram infrastructure solutions}

For the tasks planned for implementation in WPT, a number of less conventional solutions for tram routes have been outlined. The following types of solutions may be mentioned:

1. a section with the track running on the outer edge of the roadway (Swojczycka Street), 
2. "big" loops with unidirectional streets (Grabiszyn, Leśnica),

3. "Stitching" the tram route with the railway stop (Swojczyce, Grabiszyn),

4. One level intersection with the railway line (Agrestowa Street and others).

5. running in a densely built housing estate (Promenady Wrocławskie),

6. limit switches - including to the routes temporary ending,

7. use of depot areas (active / closed),

8. Track without regular movement (to make the depot more flexible),

9. sections (not completely) underground, cf. [4].

The term "outlined" was used because the program is a preliminary one, initiating only more thorough studies, including the possibility to choose variants also with public consultations. Outlined ideas are developed, inter alia through this publication. The second part of the article discusses solutions from the first two points. Further solutions will be the subject of other publications.

\section{Section with tracks on the outer edge of the roadway}

The proposed route to the railway line and the Swojczyce stop (planned for a new location) of about $1.5 \mathrm{~km}$ is shown in Figure 3. The starting point is at the current Sępolno loop (mark 3). The final loop (4) will be located at the proposed stop (6). The railway station should be located on the south side of the track (monorail line), so that both sides of the railroad cross the road: from the north (in both directions), from the south tram (towards the city center). The WPT plans to extend the tram routes to Mydlana Street (5) to Zakrzów (Olsztyn route) in the longer term - according to the study [5]. It is assumed that the construction of new Swojczycki bridges in the existing track but with greater width and axial displacement of the bridge towards the flow of water (northwest). The new bridges will be located on a separate tram track (built in the emergency road) and a carriageway on one lane in each direction. Other elements will be bilateral sidewalks and belts for cyclists.

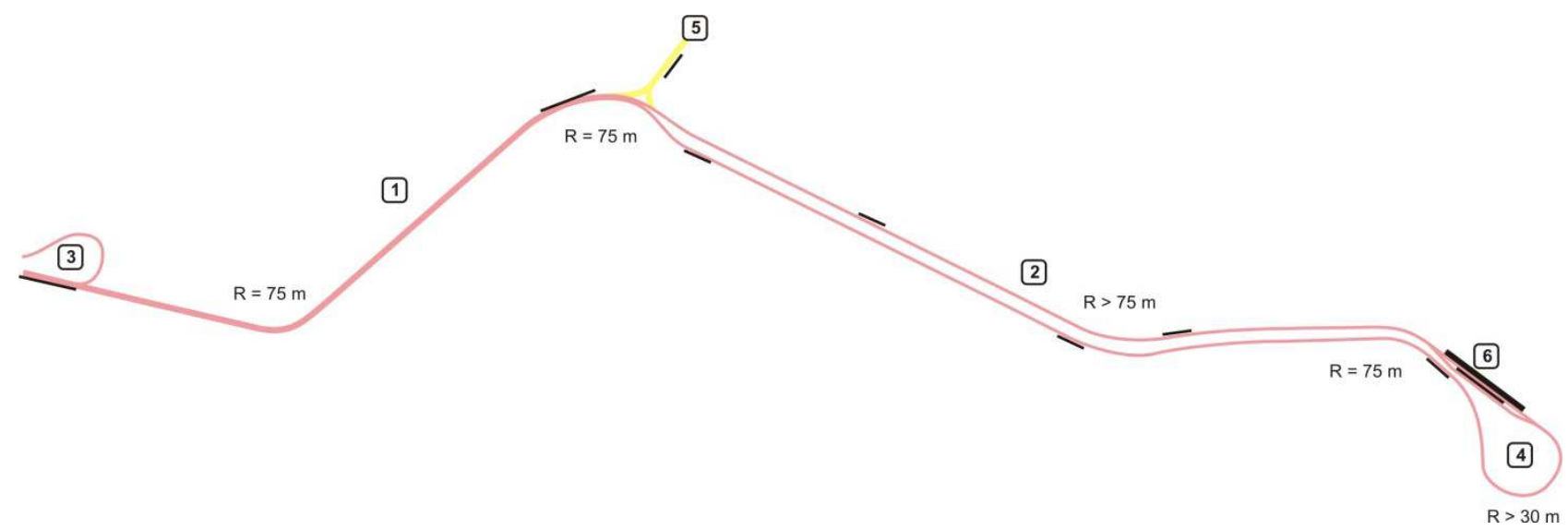

3. Suggested route through Swojczycka street [6]

In the section of the Sępolno loop to the Mydlana Street the track (1) is run on the northern side of the existing road - as a continuation of the track at Mickiewicza Street and for further continuation on Mydlana Street. It is recommended that the track be built up in spite of the lack of regular bus routes in this section (for use in emergency situations of bus lines, privileged vehicles, etc.). In the further section of Swojczycka Street (2) the tracks are proposed on both sides of the roadway (two extreme lanes) in the convention of bus and tram lanes - according to Figure 4. This will allow sparingly management of the street space (stops integrated with sidewalks), excellent interchanges bus - tram and probably minimize the scope of reconstruction of Swojczycka Street (leaving the existing roadway for general traffic). Figure 4 shows the following signs for the crosssection of the street: $\mathrm{J}$ - carriageway (general traffic), PAT - bus and tram lanes (built tram track), $\mathrm{CH}$ - pavement, $\mathrm{P}$ - stop, R - bicycle track. Picture 5 shows the available lane space (limited by fences highlighted with green arrows). 


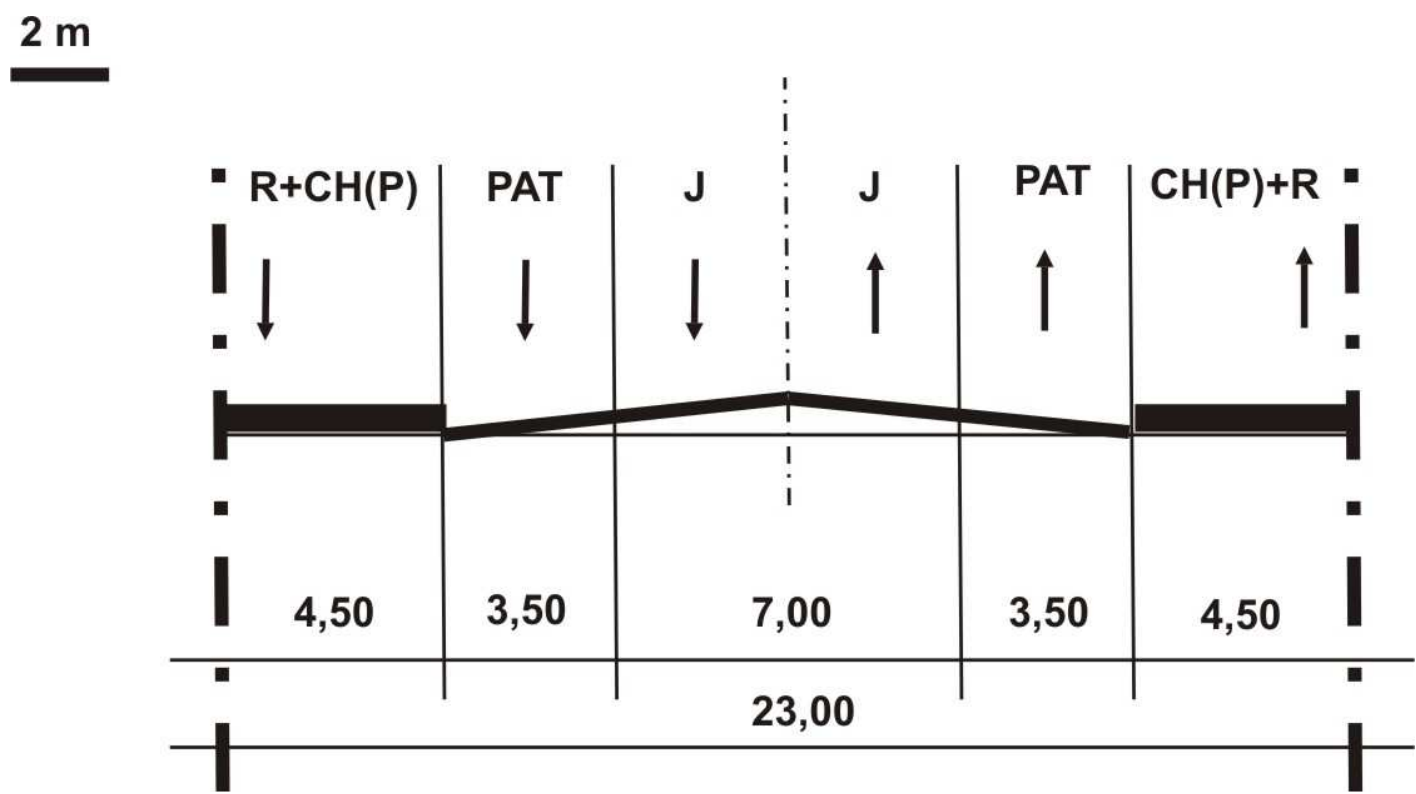

4. The proposed location of the tram track on Swojczycka Street (cross-section) [6]

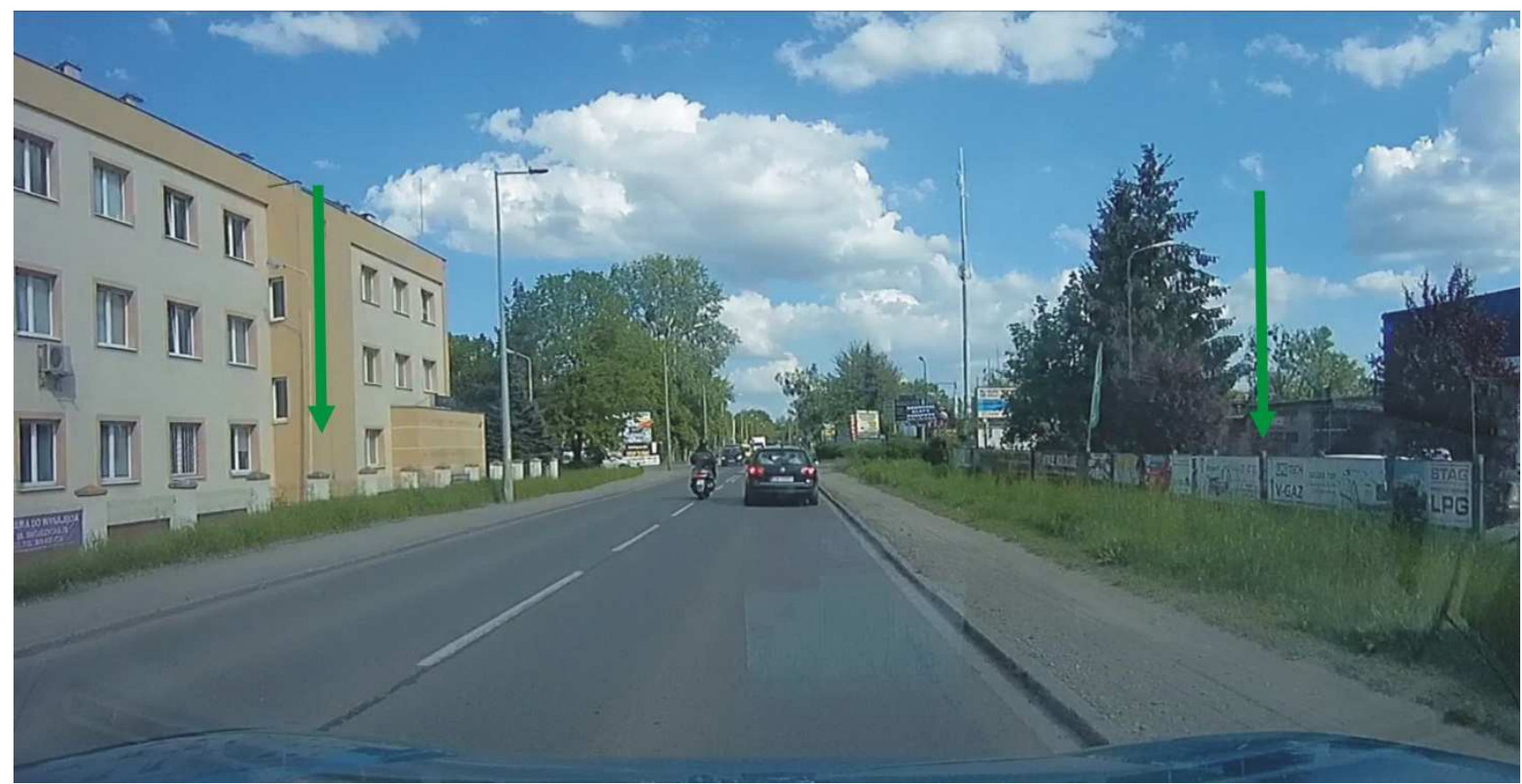

5. A view of the current development of the Swojczycka street area in the place of the considered tramway track.

\section{Large loops held on one-way streets}

The "big loops" are defined here as running a part of the tram route with unidirectional segments to the final stop (in the form of several tracks and platforms). In WPT, this solution is offered in two locations: Leśnica and Grabiszyn. In both cases as the supply of tram tracks to railway stations / stops.

In the Leśnica housing estate (Figure 6) it is proposed to extend the track (orange line) from the current loop (sign 2) to the railway station Wroclaw Leśnica (1) at a distance of about $400 \mathrm{~m}$ (length of a single track about $800 \mathrm{~m}$ ). The track will be run on the principle of one-way sections: Płońskiego Street to the west and Rubczaka Street in the east. The present cross-section of these streets would be transformed into a separate lane with a tram track (with the possible admission of 
buses), a general traffic lane in the opposite direction (violet arrows), a parking lane (according to need and reserve), a sidewalk and possibly a cycling track. The position of these elements in the cross-section is shown in Figure 7 (with signs: 1 - tramway belt, 2 - general traffic belt "upstream", 3 - stop lane).

In the area of the railway station, in the triangle between the streets and railways (position number 3 in Figure 6) provides for the $\mathrm{P}+\mathrm{R}$ parking lot - hence indicated variants carry the tram track (dashed line) depends on the layout of the target and the entrances to the parking lot.

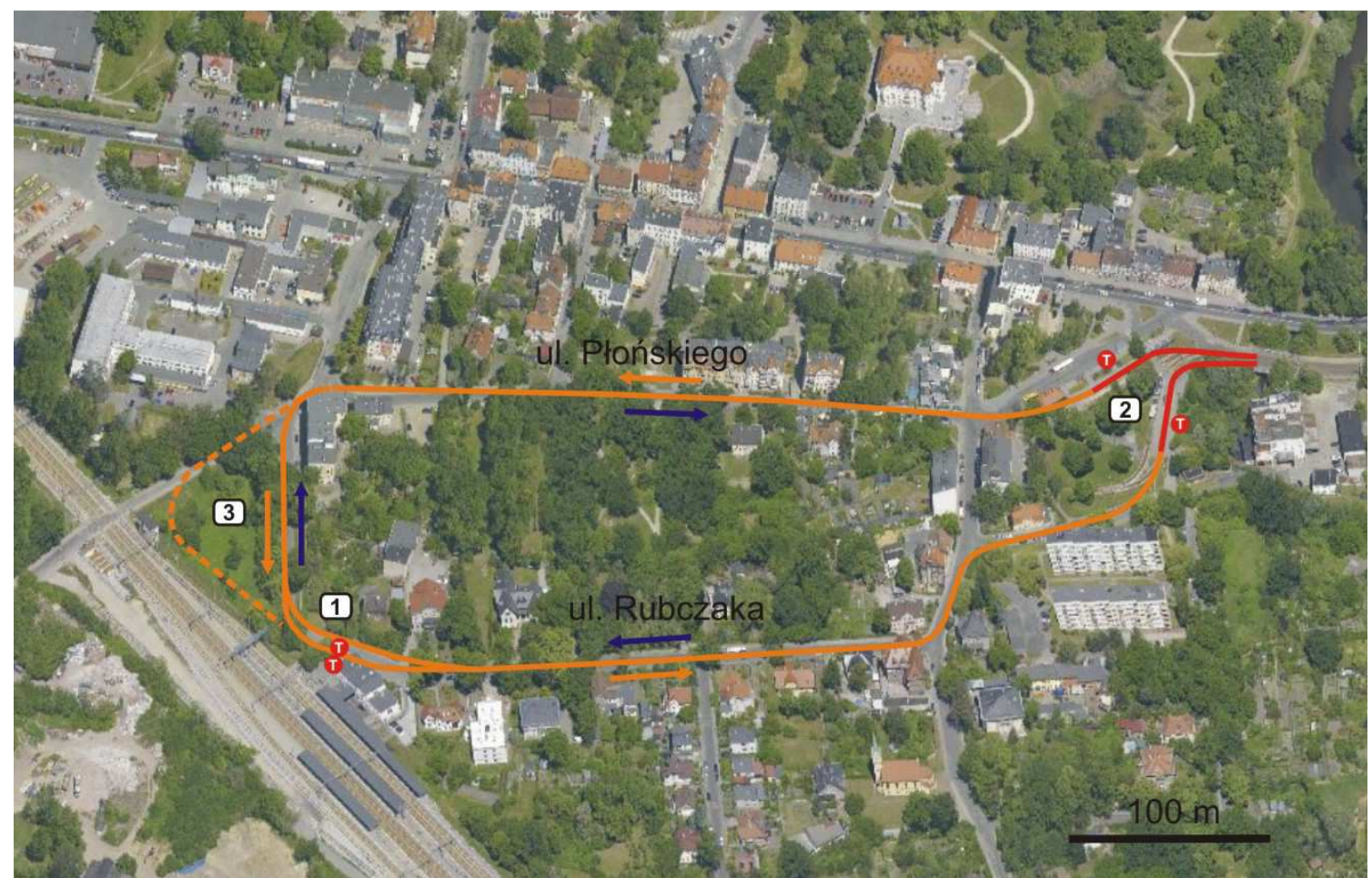

6. Proposed extension of tram route to Wroclaw Leśnica station, drawing on picture from http://ukosne.gis.um.wroc.pl/

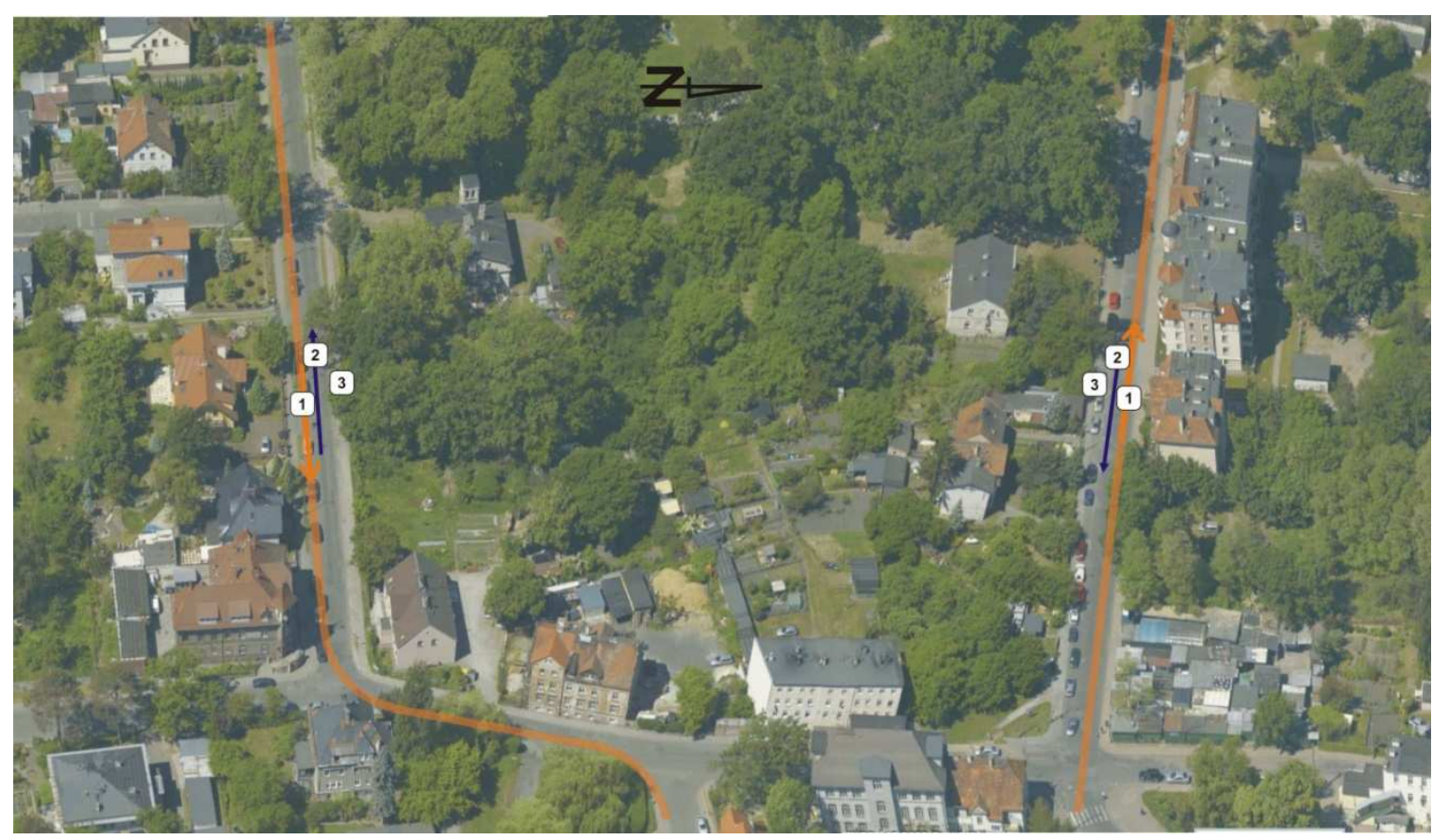

7. Proposed position of the tram track on the streets: Płońskiego and Rubczaka, drawing on the picture from http://ukosne.gis.um.wroc.pl/ 
In the area conventionally referred to as "Grabiszyn" (due to the naming of the railway stop) - figure 8, it is proposed to make a track from the intersection of Klecińska and Grabiszynska Street to Grabiszyn railway stop (mark 1) at a distance of about $500 \mathrm{~m}$ (length of a single track about 1000 $\mathrm{m} \mathrm{m}$ ). The track (orange line) would be run on a one-way circuit between the Streets of Klecińska, between Petuniowa Street and the railway tracks (the final tram and interchange for the railway) and Ostrowskiego Street. The latter would remain unidirectional for the general traffic (in contrast to tramways i.e. from Grabiszyńska) - only in a short distance before Grabiszyńska Street (2) so as not to block the track by cars waiting to enter the traffic (the tramway entrance would be supervised by the excitation signal ). On the other side of Ostrowski Street, the traffic would be on the same track as the tramway. Access to Grabiszyńska Street would be possible by the adjacent streets marked in Figure 8 with purple arrows (this requires a local change of organization of the traffic and local interference in the intersection geometry).

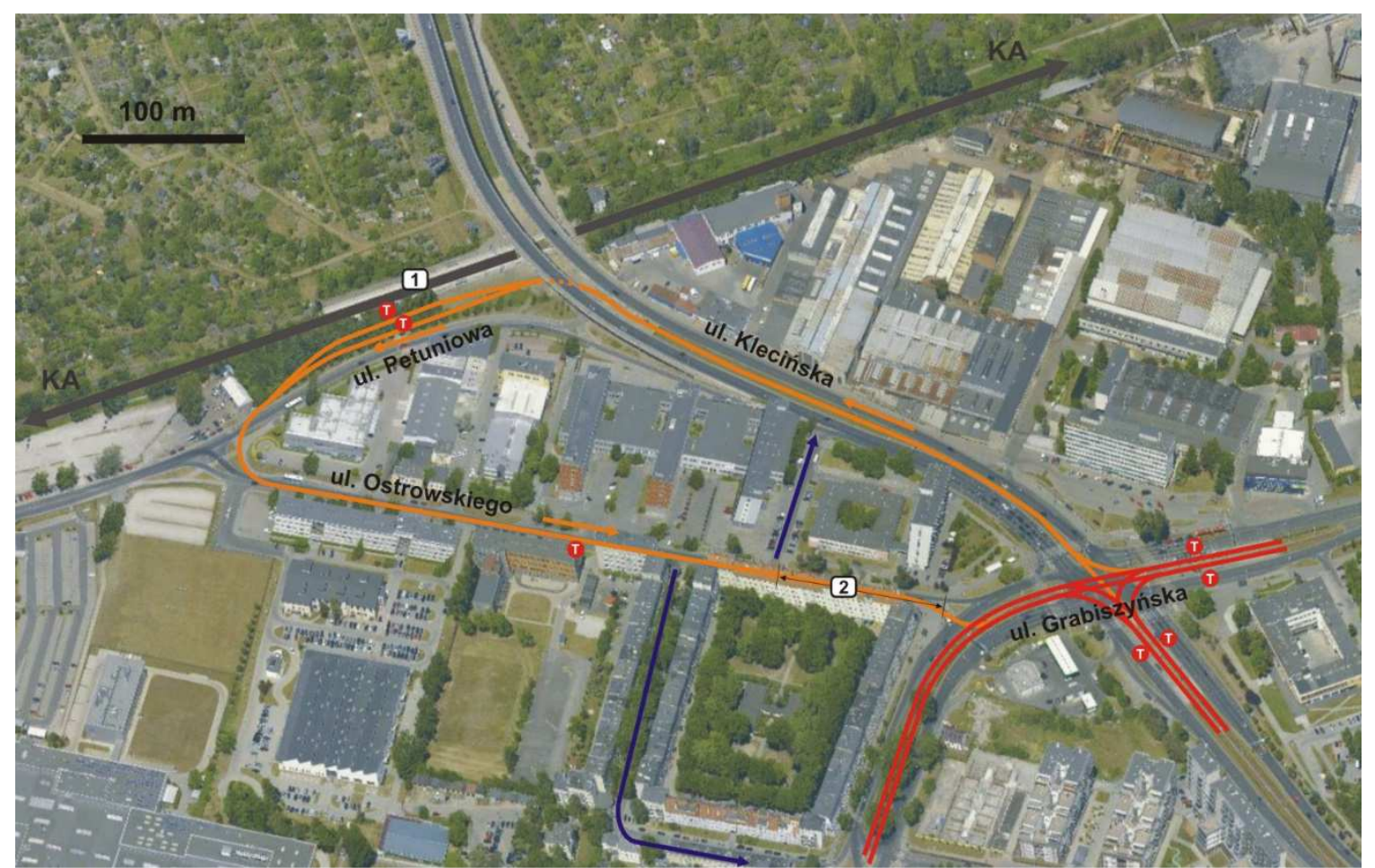

8. Proposed extension of the tram route to Wroclaw Grabiszyn tram stop, drawing on picture from http://ukosne.gis.um.wroc.pl/

More specifically the proposed use of space Ostrowski Street shown in Figure 9 are the following elements: 1 - Ostrowski Street segment with built-in track tram and the allowed movement general 2 - Ostrowski Street segment wih excluded tramways movement in the direction of the Grabiszynska Street (lane remains embedded in roadways 3 - tram stop, 4 - new pedestrian crossing, 5 - change of cross-section of the pedestrian crossing with levitation training, 6 - parking space. 


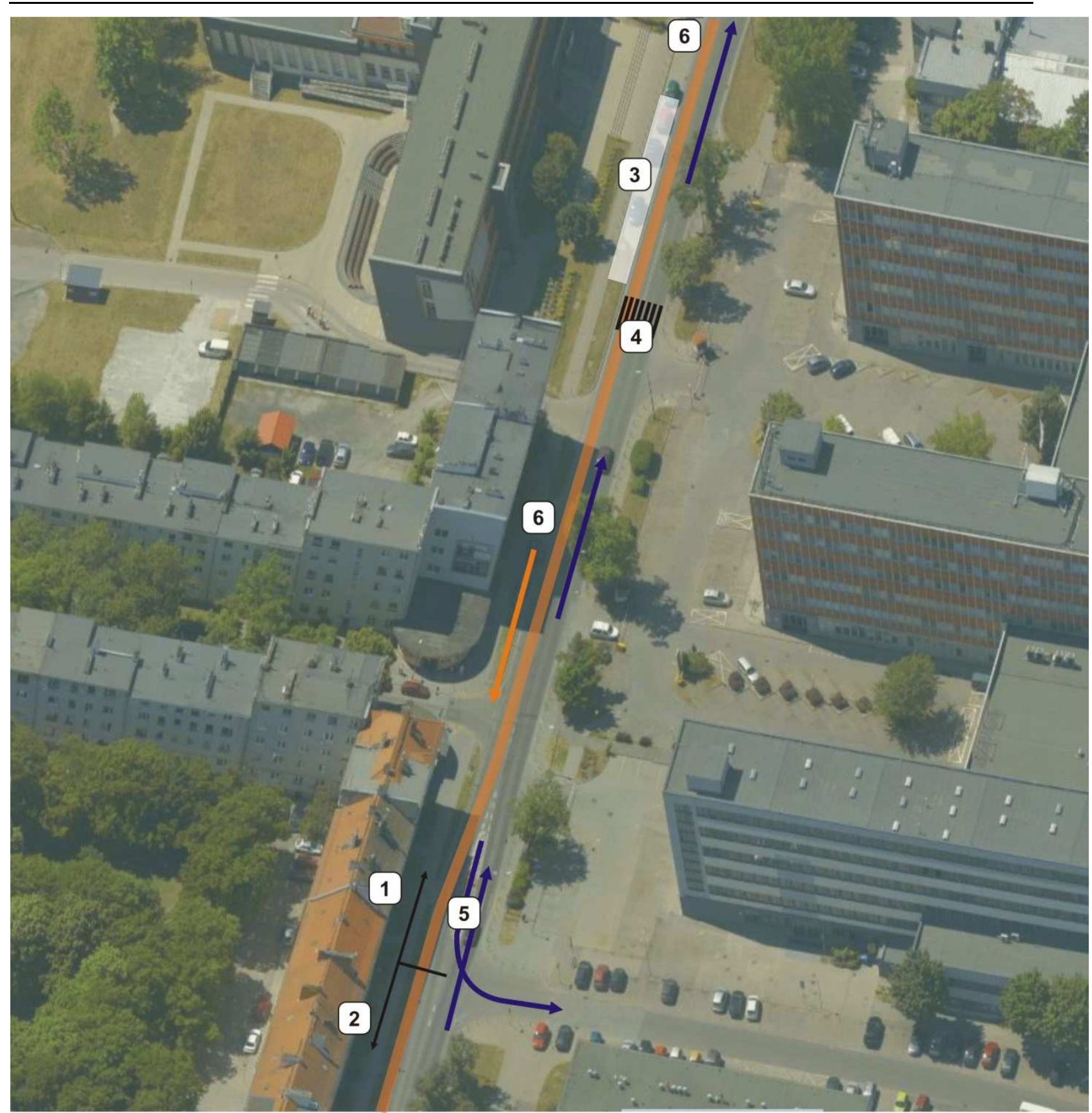

9. Proposed position of the tram track on Ostrowskiego Street, drawing on the photo from http://ukosne.gis.um.wroc.pl/

\section{Summary}

So far, the investments tram in Poland were usually associated with the expansion of the road system. There have been some spectacular departures from the route of the common corridor (e.g. the tunnel at the main railway station and the overpass of the Płaszów railway station in Cracow, or several sections in Poznań headed by the PST). Still, in the minds of planners, decision-makers and designers, too little is bold in carrying out tasks involving only tram infrastructure, running these routes independently of the road system, introducing less conventional solutions.

The multi-annual and multi-purpose investment program is a good opportunity to implement a variety of solutions, including less conventional ones. The demand for investment means more efficient, but less expensive. It is therefore a WPT-type program that stimulates the use of numerous exemplary implementations as well as a field for the implementation of individual innovations.. In conclusion, the advantages of the proposed less conventional solutions include: entering the tram route into the lane, low investment costs, priority for tramways, leaving local service and parking 
places, calming traffic, increasing the flexibility and accessibility of the tramway network with rail integration.

Economical spending and efficiency search do not mean that the proposed solutions are not safe and functional. Emphasis on effects is directed towards the improvement of urban transport. But the presented solutions do not deteriorate the infrastructure parameters for other users. An example is the proposal for the development of street space. Introducing unidirectional traffic in a local environment, without sacrificing throughput or availability. It only enhances the aspect of calming the movement. In the case of Swojczycka Street, tram lanes are added to the existing roadway. It should be emphasized that the construction of a new tramway route does not (and should not) imply increasing the capacity of the road system, which would (and often would) be the case with the simultaneous construction of a tramway and widening the street (increasing the number of lanes or roads).

\section{Source materials}

[1] Calvet B., Klemba S. „Możliwości i efekty zastosowania priorytetów dla tramwajów na przykładzie sieci tramwajowej Gdańska”, Przegląd Komunikacyjny 11-12/2011

[2] Gisterek I. „Deja vu - czyli nowoczesne rozwiązania w transporcie szynowym dawniej i dziś", Przegląd Komunikacyjny 8/2014

[3] Grulkowski S., Zariczny J. „Propozycja usprawnień infrastrukturalno-organizacyjnych sieci tramwajowej w Toruniu", Przegląd Komunikacyjny 9-10/2011

[4] Kruszyna M. „Propozycja wprowadzenia odcinków podziemnych w transporcie zbiorowym Wrocławia” Transport Miejski i Regionalny 12/2015

[5] Kruszyna M., Makuch J., Szydło A. „Plan rozwoju wrocławskiej komunikacji tramwajowej wraz z infrastrukturą towarzyszącą do roku 2032 z perspektywą kontynuacji w kolejnych latach" Raport Wydziału Budownictwa Politechniki Wrocławskiej z serii SPR nr 21/2016.

[6] Kruszyna M. „Szczegółowe analizy wybranych inwestycji dotyczących rozbudowy tras tramwajowych we Wrocławiu" opracowanie dla UM Wrocławia, grudzień 2016.

[7] Madras G. „Budowa trasy tramwaju szybkiego do Wilanowa”, Przegląd Komunikacyjny $7 / 2016$

[8] Makuch J. „Propozycja niekonwencjonalnego sposobu prowadzenia nowej linii tramwajowej”, Przegląd Komunikacyjny 9/2015

[9] Popiołek A. „Wpływ nowoczesnych rozwiązań stosowanych w komunikacji tramwajowej na estetykę przestrzeni miejskiej”, Przegląd Komunikacyjny 8/2014

[10]Rychlewski J. „Sygnalizacja na tramwajowej trasie przez most św. Rocha w Poznaniu z punktu widzenia pasażera", Przegląd Komunikacyjny 11-12/2011

[11]Rychlewski J. „Planowanie tras tramwajowych w miejskiej sieci ulic”, Przegląd Komunikacyjny $9 / 2015$

[12]“Strassen und Plaetze neu Gestaltet”, Kirchbaum Verlag, Bonn 1997.

[13]Uchwała nr XXXIV/713/16 Rady Miejskiej Wrocławia z dnia 22 grudnia 2016 r. w sprawie "Planu zrównoważonego rozwoju publicznego transportu zbiorowego dla Wrocławia na lata 2016 - 2022" Dziennik Urzędowy Województwa Dolnośląskiego z 2017 r. poz.200. [Data ogłoszenia: 12 stycznia 2017 r.]

[14] Wrocławski Program Tramwajowy (informacja ze strony internetowej) http://www.wroclaw.pl/wroclawski-program-tramwajowy-cele 